\title{
The Occurrence of HIV-1 Resistance Biomarker Among Two Cohorts from Poland
}

\author{
Aleksandra Siekierzynska ${ }^{1,2 *}$, Aleksander Myszka1,2, Ryszard Slezak ${ }^{3}$, Izabela Laczmanska ${ }^{3}$ and Maciej Wnuk $^{1,2}$ \\ ${ }^{1}$ Department of Genetics, University of Rzeszow, 35-959 Rzeszow, Poland \\ ${ }^{2}$ Centre of Applied Biotechnology and Basic Sciences, University of Rzeszow, 36-100 Kolbuszowa, Poland \\ ${ }^{3}$ Department of Genetics, Wroclaw Medical University, 50-368 Wroclaw, Poland
}

\begin{abstract}
Approximately $1 \%$ of the Caucasians shows resistance to HIV- 1 infection conditioned by $32 \mathrm{bp}$ deletion in CCR5 gene. Homozygotes are almost totally resistant, but heterozygotes have delay the progression to AIDS. Due to the constantly increase of HIV infection in Poland we examined the incidence of del32 allele in two cohorts (south-western and south-eastern region of country) that remarkably differs in the incidence of HIV. Among the individuals from the south-western region, we detected 7 homozygotes $(2.6 \%)$, in compare with individuals from the south-eastern area of Poland, where we found 1 homozygote $(0.4 \%)$. The prevalence of CCR5del32 allele in the group from the southwestern region was estimated at $11.6 \%$, while in the group from the south-eastern region was assessed at $9.7 \%$. Differences in the prevalence of genotypes and alleles between regions were not statistically significant. Our results were discussed in relation to the incidence of HIV infection in Poland. We conclude that occurence of CCR5del32 biomarker does not reflect the incidence of HIV in the examined regions.
\end{abstract}

\section{Introduction}

In the aetiology of HIV-1 infection, some genetic factors may be important, for example the gene variants, which encode chemokine receptors: CCR5, CCR2 and CXCR4 - SDF-1 ligand receptor [1]. The human $\beta$-chemokine receptor is encoded by CCR 5 gene located in the 3 p21.3 locus. CCR5 consists of four exons and two introns; exon 4 contains ORF (open reading frame). The deletion of $32 \mathrm{bp}$ in the ORF causes the formation of non-functional protein and protects homozygotes against HIV-1 R5 infection [2-5]. This alteration decreases, in heterozygotes, risk of infection [6] and delays progression into AIDS for about 2-3 years [3,5,7]. There are some evidence that the resistance of this type is related to the Caucasian due to spreading epidemies of diseases with similar pathogenesis to HIV infection. One hypothesis states that people with the deletion of 32 bp in CCR 5 gene could have survived the episemies, and allele with deletion could been inherited by progeny. Bubonic plaque (1347 - 1351 year) [8] as well as smallpox could have also had a selective pressure on chemokine receptors $[9,10]$. An alternative hypothesis states that allele with deletion could have been conveyed by Vikings between $8^{\text {th }}$ and $10^{\text {th }}$ century [11]. Nowadays, the CCR5del32 biomarker occurs approximately in $1 \%$ of the Caucasian population [2].

The aim of our study was to examine the occurrence of CCR5del32 biomarker in two population groups from the south-western and south-eastern regions of Poland. Our results were compared with epidemiology data of HIV infection in this region.

\section{Materials and Methods}

The study involved 268 individuals from the south-western (dolnośląskie) region of Poland and 252 individuals from the southeastern (podkarpackie) region, altogether 520 subjects chosen randomly. The group was matched according to sex and age. The age of respondents was in the range between 20-29 years. DNA was obtained from peripheral blood lymphocytes (268 sample), buccal cells (125 samples) and hair follicle cells (13 samples). DNA from peripheral blood lymphocytes was isolated by fenol-chloroform extraction; from buccal cells and hair follicle cells by alkaline lysis according to Bolla [12] and Klintshaar methods with minor modifications [13].
Molecular analysis of CCR5del32 (c.794-925del) variant was carried out with PCR technique, using primers described previously by Liu et al. [4]. The PCR reaction mixture in the total volume of 10 $\mu$ l per tube contained: $0.2 \mathrm{mM}$ dATP, dCTP, dGTP and dTTP, 0.5 U/ $\mu$ l OptiTaq DNA Polymerase (EURx, Poland), 1x Taq polymerase buffer; $1.5 \mathrm{mM} \mathrm{MgCl}, 0.5 \mu \mathrm{M}$ Fwd primer and $0.5 \mu \mathrm{M}$ Rev primer. PCR conditions were: 25 seconds at $95^{\circ} \mathrm{C}, 25$ seconds at $62^{\circ} \mathrm{C}, 25$ seconds at $72^{\circ} \mathrm{C}, 35$ cycles. Results of PCR amplification were visualized on $2 \%$ agarose gel stained with SYBR Safe DNA gel stain (Invitrogen, Carlsbad, CA, USA). Band of about 182 bp was characteristic for wild type homozygotes (wt/wt), about $150 \mathrm{bp}$ band was characteristic for homozygotes with $32 \mathrm{bp}$ deletion (del32/del32), two bands (182 bp and $150 \mathrm{bp}$ ) were characteristic for heterozygote (wt/del32).

Analysis of the frequency of del32 variant in the CCR5 gene was assessed using the Pearson $\chi 2$ test. Statistical analysis of data was performed using StatSoft, Inc. (2005) STATISTICA, version 7.0, http:// www.statsoft.com. This study protocol was approved by the Ethics Committee of the Faculty of Medicine, University of Rzeszow, Poland.

\section{Results}

Among the individuals from the south - western region of Poland deletion was detected in $55(20.5 \%)$ cases, including 7 homozygotes (2.6\%). In individuals from the south - eastern region deletion was found in 48 (19\%) subjects, including one homozygous case $(0.4 \%)$. The prevalence of CCR5del32 was assessed at $11.6 \%$ and $9.7 \%$ (south - western and south - eastern province respectively, see Table 1). The differences in the prevalence of genotypes and alleles between regions

*Corresponding author: Aleksandra Siekierzynska, 1Department of Genetics, University of Rzeszow, 35-959 Rzeszow, Poland, E-mail: ola_sk@wp.pl

Received May 30, 2011; Accepted June 20, 2011; Published June 27, 2011

Citation: Siekierzynska A, Myszka A, Slezak R, Laczmanska I, Wnuk M (2011) The Occurrence of HIV-1 Resistance Biomarker Among Two Cohorts from Poland. J Mol Biomark Diagn 2:108. doi:10.4172/2155-9929.1000108

Copyright: (c) 2011 Siekierzynska A, et al. This is an open-access article distributed under the terms of the Creative Commons Attribution License, which permits unrestricted use, distribution, and reproduction in any medium, provided the original author and source are credited 


\begin{tabular}{|c|c|c|c|c|}
\hline \multicolumn{5}{|c|}{ Region } \\
\hline & south-western & south - eastern & Total & $p$ value \\
\hline \multicolumn{5}{|l|}{ Genotypes } \\
\hline wt/wt & $213(79.5 \%)$ & 204 (81\%) & $417(80.2 \%)$ & \multirow{3}{*}{0.12} \\
\hline wt/del32 & $48(17.9 \%)$ & $47(18.6 \%)$ & $95(18.3 \%)$ & \\
\hline del32/del32 & $7(2.6 \%)$ & $1(0.4 \%)$ & $8(1.5 \%)$ & \\
\hline Total & 268 & 252 & 520 & \\
\hline \multicolumn{4}{|l|}{ Alleles } & \multirow{3}{*}{0.33} \\
\hline del32 & $62(11.6 \%)$ & $49(9.7 \%)$ & $111(10.7 \%)$ & \\
\hline wt & $474(88.4 \%)$ & 455 (90.3\%) & 929 (89.3\%) & \\
\hline Total & 536 & 504 & 1040 & \\
\hline
\end{tabular}

Table 1: The CCR5/CCR5del32 frequency and genotype distribution in the southwestern and south-eastern Polish population.

were not statistically significant ( $\mathrm{p}=0.12$ and $\mathrm{p}=0.33$ respectively). Our results were discussed in relation to the incidence of HIV infection in Poland.

\section{Discussion}

Recently in Poland, has been noticed increasing amount of infections caused by HIV, especially in western region of Poland [14]. In the face, the growing number of reported HIV infections it is important to predict the factors likely to influence the incidence of infections. Faced with an increasing number of reported HIV infections is a selection of important factors that may affect the incidence of infections. One of such factors is the genetic resistance caused by 32 bp deletion in CCR5 gene can have the effect on limitation of infection. In Europe the prevalence of $32 \mathrm{bp}$ deletion in the human $\beta$-chemokine receptor gene is ranked between $16 \%$ in the North Europe to $4 \%$ in the South Europe [15-25]. In Poland the frequency of deletion was assessed at $10.9 \%$ [26].

In our study we investigated the incidence of CC5del32 variant in two distant cohorts from the south-western and south-eastern region of Poland that differ in the incidence of HIV. In south - western region HIV infections were observed in 4.1 per 100'000 inhabitants (in 2004 - 2008) and were the greatest in Poland. In turn, in south - eastern region HIV was found in 0.6 per $100^{\prime} 000$ inhabitants and was one of the smallest amounts of infected cases in Poland [14]. We observed slightly higher frequency of del32 allele in the south-western territory than in the south-eastern. However the prevalence of CCR5del32 variants between regions were not differs significant. Moreover the frequency of deletion in the south-western and the south-eastern regions are not compatible with the incidence of infections in these regions. We conclude that occurrence of CCR5del32 biomarker does not reflect the incidence of HIV in the examined regions. Studies on larger groups could explain this phenomenon.

Very similar distribution of CCR5del32 variant among inhabitants of this distinct region can be the result of the recently described genetic homogeneity of Polish population [27]. On the other hand, it is possible that the comparable values of del 32 allele frequency can be the cause of increasing migration of people from the south-eastern to south-western Poland after the Second World War [26].

Due to the relatively high incidence of deletion in the study groups (about $20 \%$ individuals) should be noted, that the deletion can have the impact on incidence of other diseases. The latest studies revealed that CCR5del32 variant is a modifying pathogenetic factor in type I diabetes [28]. By analyzing morbidity type I diabetes on population level, should be taken into account CCR5del32 biomarker as risk factor.

This finding might be useful for epidemiological researches of HIV infections and other diseases like diabetes. Moreover our data may be useful for planning prevention efforts.

\section{References}

1. Kozhekbaeva ZhM, Borodina TA, Borinskaya SA, Gusar VA, Feschenko SP, et al. (2004) Distribution of the HIV-1 Resistance-Conferring Alleles (CCR5delta32, CCR2-64I, and SDF1-3'A) in Russian, Ukrainian, and Belarusian Population. Russian Journal of Genetics 40: 1149-1155

2. Samson M, Libert F, Doranz BJ, Rucker J, Liesnard C, et al. (1996) Resistance to HIV-1 infection in individuals bearing mutant alleles of the CCR- 5 chemokine receptor gene. Nature 382: 722-725.

3. Dean M, Carrington M, Winkler C, Huttley GA, Smith MW, et al. (1996) Genetic restriction of HIV-1 infection and progression to AIDS by deletion allele of the CKR structural gene. Science 273:5283.

4. Liu R, Paxton WA, Choe S, Ceradini D, Martin SR, et al. (1996) Homozygous defect in HIV-1 coreceptor accounts for resistance to HIV-1 infection. Cell 86 : 367-377.

5. Eugen-Olsen J, Iversen AKN, Garred P, Koppelhaus U, Pedersen C, et al (1997) Heterozygosity for deletio in the CKR-5 gene leads to prolonged AIDSfree survival and slower CD4 T-cell decline in a cohort of HIV-seropositive individuals. AIDS 11: 305-310.

6. Marmor M, Sheppard HW, Donnell D, Bozeman S, Celum C, et al. (2001) Homozygous and heterozygous CCR5 $\triangle 32$ genotypes are associated with resistance to HIV. J AIDS 27: 472-481.

7. Gilvani AP, Novembre J (2005) The evolutionary history of the CCR5- $\triangle 32 \mathrm{HIV}$ resistance mutation. Microbes and Infection 7: 302-309.

8. Altschuler EL (2006) Plague as HIV vaccine adjuvant. Med Hypotheses 54:1003-1004.

9. Goldrick BA (2003) Bubonic plague and HIV. The delta 32 connection. Am J Nurs 103: 26-27.

10. Galvani AP, Slatkin M (2003) Evaluating plague and smallpox as historica selective pressures for the CCR5-Delta 32 HIV-resistance allele. Proc Nat Acad Sci U S A 100: 15276-15279.

11. Lucotte G, Dieterlen F (2003) More about the Viking hypothesis of origin of the delta32 mutation in the CCR5 gene conferring resistance to HIV-1 infection. Infect Genet Evol 3: 293-295

12. Bolla MK, Haddad L, Humphries SE, Winder AF, Day IN (1995) High-throughput method for determination of apolipoprotein $E$ genotypes with use of restriction digestion analysis by microplate array diagonal gel electrophoresis. Clin Chem 41:1599-1604

13. Klintschar M, Neuhuber F (2000) Evaluation of an alkaline lysis method for the extraction of DNA from whole blood and forensic stains for STR analysis. J Forensic Science 45:669-673.

14. National Institute of Public Health - National Institute of Hygiene.

15. Ryabov GS, Kazennova EV, Bobkova MR, Bobkov AF (2004) Prevalence of alleles associated with HIV resistance in Russia. Genet Test 8: 73-76.

16. Lucotte $G(2002)$ Frequencies of 32 base pair deletion of the $(\Delta 32)$ allele of the CCR5 HIV-1 co-receptor gene in Caucasians: a comparative analysis. Infect Genet Evol 1: 201-205.

17. Hummel M, Bara C, Hirt S, Haverich A, Hetzer R (2007) Prevalence of CCR5Delta32 polymorphism in long-term survivors of heart transplantation. Transpl Immunol 17:223-226.

18. Limborska SA, Balanovsky OP, Balanovskaya EV, Slominsky PA, Schadrina MI et al. (2002) Analysis of CR5Delta32 geographic distribution and its correlation with some climatic and geographic factors. Hum Hered 53: 49-54.

19. Ristić S, Starcević Cizmarević N, Brajenović-Milić B, Crnić-Martinović M Kapović M (2005) Frequency of CCR5 gene 32-basepair deletion in Croatian normal population. Croat Med J 46: 693-694.

20. Petrkova J, Cermakova Z, LukI J, Petrek M (2005) CC chemokine receptor 5 (CCR5) deletion polymorphism does not protect Czech males against early myocardial infarction. J Intern Med 257: 564-566.

21. Oh DY, Jessen H, Kücherer C, Neumann K, Oh N, et al. (2008) CCR5Delta32 genotypes in a German HIV-1 seroconverter cohort and report of HIV-1 infection in a CCR5Delta32 homozygous individual. PLoS One 3: 2747. 
Citation: Siekierzynska A, Myszka A, Slezak R, Laczmanska I, Wnuk M (2011) The Occurrence of HIV-1 Resistance Biomarker Among Two Cohorts from Poland. J Mol Biomark Diagn 2:108. doi:10.4172/2155-9929.1000108

Page 3 of 3

22. Petrek M, Cermáková Z, Hutyrová B, Miceková D, Drábek J, et al. (2002) CC chemokine receptor 5 and interleukin-1 receptor antagonist gene polymorphisms in patients with primary Sjögren's syndrome. Clin Exp Rheumatol 20: 701-703.

23. Rossol M, Pierer M, Arnold S, Keysser G, Burkhardt H, et al. (2009) Negative association of the chemokine receptor CCR5 d32 polymorphism with systemic inflammatory response, extra-articular symptoms and joint erosion in rheumatoid arthritis. Arthritis Res Ther 11: R91.

24. Farue E, Royer-Carenzi M (2009) Is the European spatial distribution of the HIV-1-resistant CCR5-D32 allele formed by a breakdown of the pathocenosis due to the historical Roman expansion? Infect Genet Evol 9: 387-389

25. Smoljanović M, Ristić S, Hayward C (2006) Historic exposure to plague and present-day frequency of CCR5del32 in two isolated island communities of Dalmatia, Croatia. Croat Med J 47: 579-584

26. Jagodziński PP, Lecybył R, Ignacak M, Juszczyk J, Trzeciak WH (2000) Distribution of the $\Delta 32$ alelle of the CCR5 gene in the population of Poland. $J$ Hum Genet 45: 271-274.

27. Ploski R, Wozniak M, Pawlowski R, Monies DM, Branicki W, et al. (2002) Homogeneity and distinctiveness of Polish paternal lineages revealed by $Y$ chromosome microsatellite haplotype analysis. M Hum Genet 110: 592-600.

28. Kalev I, Oselin K, Parlist P, Zilmer M, Rajasalu T, et al. (2003) CC-chemokine receptor CCR5- $\triangle 32$ mutation as a modifying pathogenetic factor in type-l diabetes. J Diabetes Complications 17:387-391. 